\title{
CAN INFOGRAPHICS FACILITATE THE LEARNING OF INDIVIDUALS WITH MATHEMATICAL LEARNING DIFFICULTIES?
}

\author{
Dr. Basak Baglama, Department of Special Education, Atatürk Education Faculty, Near East University, North \\ Cyprus, Mersin 10 Turkey \\ E-mail: basak.baglama@neu.edu.tr \\ Dr. Yucehan Yucesoy, Department of Teaching Arts, Atatürk Education Faculty, Near East University, North \\ Cyprus, Mersin 10 Turkey \\ E-mail: yucehan.yucesoy@neu.edu.tr \\ Dr. Huseyin Uzunboylu, Department of Educational Sciences, Atatürk Education Faculty, Near East University, \\ Mersin 10 Turkey \\ E-mail: huseyin.uzunboylu@neu.edu.tr \\ Dr. Deniz Özcan, Near East University, Ataturk Faculty of Education, Near East University, Mersin 10 Turkey \\ E-mail: deniz.ozcan@neu.edu.tr
}

\section{ART I C LE IN F O \\ Studies and Articles \\ Received: September, 27.2017. \\ Revised: December, 05.2017. \\ Accepted: December, 11.2017. \\ doi:10.5937/IJCRSEE1702119B \\ UDK \\ 371.3::51]:004}

\section{Keywords:}

infographics,

teaching mathematics,

mathematical learning difficulties,

dyscalculia,

visualization.

\begin{abstract}
A B S T R A C T
Visualization of data has recently gained great importance in education and use of infographics is regarded as an important tool in teaching mathematics since it presents information in a clear and abstract way. Therefore, use of infographics for helping individuals with mathematical learning difficulties has become an important research question. This study aims to provide an overview on the use of infographics in teaching mathematics to individuals with mathematical learning difficulties. This is a qualitative study in which document analysis was used the collect the data. Results provided information about the definition of infographics, effectiveness of using infographics in education and facilitative role of infographics in enhancing learning of individuals with mathematical learning difficulties, namely dyscalculia. Results were discussed with relevant literature and recommendations for further research and practices were also presented.
\end{abstract}

(C) 2017 IJCRSEE. All rights reserved.

\section{INTRODUCTION}

Visualization is an effective method for learners to understand complicated knowledge in learning-teaching process (Keller and Tergan, 2005). Accordingly, data visualization is a strategy to make the data visible, available and clear for learner to structure, organize,

\section{Corresponding Author}

Dr. Huseyin Uzunboylu, Atatürk Education Faculty, Near East University, Mersin 10 Turkey

E-mail: huseyin.uzunboylu@neu.edu.tr

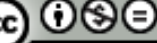

This work is licensed under a Creative Commons Attribution - NonCommercial - NoDerivs 4.0. The article is published with Open Access at www.ijcrsee.com evaluate, annotate knowledge and establish communication. Through the data visualization, learner has the opportunity of making data more accessible, understandable, improvable and manageable (Tong and Bakan, 2016). Graphic organizers, draft drawings, pictograms, concept maps and simulations come into prominence in data visualization. Reading and constituting visual data have become a necessity for individuals based on the increase in visual data and digital tools. According to Saban (2002), when teachers support teaching process with images and graphics, they can reach more students. This kind of strategy includes visualizing concepts and knowledge with graphical symbols. Ware and Bobrow (2005) indicated that it is important to represent complex data with internal representative 
such as mental imaging and external representatives including real objects, printed materials, video, graphics, movie and animation.

Learners frequently experience difficulties in learning conceptual knowledge and understanding multifaceted external knowledge (Chen and McGrath, 2005). In learning environments, it is aimed to facilitate and improve performance of learners through visualizing the data with various methods, techniques and strategies of technology. Nowadays, educational environments are changed and supported by various tools through technological advances. Teaching process is carried out with instructional activities and materials which transform information. Educational environments constituted with technology have led instructional activities to be carried out through computer and the internet. In recent years, digital worlds are formed and every domain of life has begun to benefit from various technologies.

One of the ways of presenting the data is visuals. Visuals are crucial in organizing the data and viewing a specific situation. For this reason, it is really important to visualize the data and use visuals in teaching environments. One of the visuals used in presenting the data is graphics (Bulduk, 2016). Graphics enables to visualize the data for comparing the data with an existing one. Furthermore, today's learning approach has revealed an effective way for presenting single dimensional data presented by classical graphics. This way is enabled by infographics and infographics as new materials is used to locate data in a desired context within certain information flow. Therefore, excessive amount of information can be presented with too little explanation. Infographics involves many components such as images, graphics, charts, texts and flowcharts. Based on its construct, infographics presents the data in a logical sequence and it emerges as an alternative structure for narrative texts about a specific subject through this feature. Infographics involves many components used in data visualization and it enables to present the data in different visual formats. It is seen that infographics has become one of the trends in today's learning approach (Williams, 2002).

There are various ways to present data. According to Weinschenk (2012), stories help learners to understand the data and establish cause and effect relationship and infographics enables to use the data through visualizing and presenting the data as a story. Transforming information and establishing communica- tion is quicker and easier through infographics since brain analyzes the data composed of images at once but it is longer to understand a text (Smiciklas, 2011).

Infographics are defined as visualization of data in a way that audience can learn complicated data easily and consume rapidly. Data involve images, motion and audio to turn into a meaning. At this point, it is important for the data to be accurate and definite. Flexible structures, enabling to visualize the data and having alternative forms are some advantages of infographics (Schroeder, 2004). The innovative aspect of infographics is the use of various components in presenting information and understanding of constructing the content (Dick, 2013). In addition, there are various software applications developed for constructing infographics including Adobe Photoshop, Illustrator, and Corel Draw. In order to prepare an effective infographics, it is required to organize the data and flow well. In this way, clear and understandable infographics which presents necessary information in an effective way are prepared. Infographics can be presented to serve for different instructional objectives. It is easy to remind existing knowledge, show relationship between concepts, explain processes and events, present lecture content and summarize the information through infographics (Meeusah and Tangkijviwat, 2013).

It can be considered that use of visual design principals made infographics more attractive. Visual design and presentation of the data are two important factors for constituting infographics in an effective way. For this reason; finding, analyzing and using the data gain more importance. Instructional models are important in preparing infographics. According to Davis and Quinn (2013), there are several steps considered when preparing infographics and these steps are provided in Figure 1. As it can be seen from the figure, the first step is to determine the objective. It is important to identify a specific objective for preparing infographics. The second step is to determine the type of infographics to use. In the third step, it is aimed to prepare infographics in a way that learners would understand easily. Lastly, it is important to make decision on which of infographics would be used in presenting the data. This step is crucial since choosing the right components would make the content easier to understand and learn. 


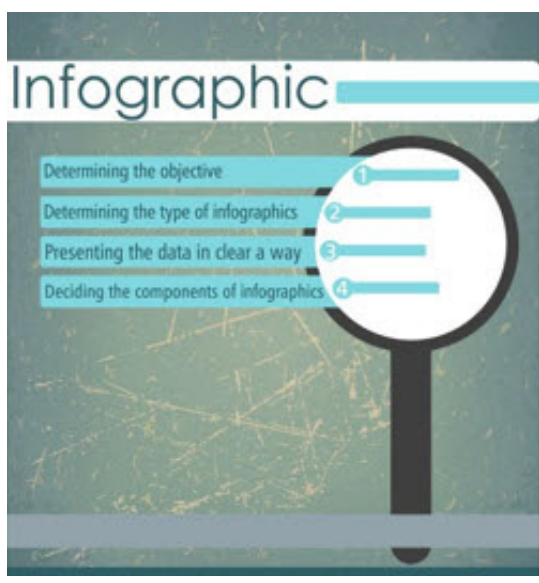

Figure 1. Preparation steps for infographics, Davis and Quinn (2013)

Through the use of infographics, individuals can learn information in an organized way and therefore a basis for schemas can be constituted in individuals' minds. Infographics are digital graphics and its use in education increase day by day. Infographics can attract attention easily, it is catchy and clear. It is a way of presenting data visually through graphics. Main structure of an infographic involves a title, text, a body and font and it is aimed to transform the data with a robust and clear narrative text. Considering these features of infographics which can be used to facilitate learning, this study aims to provide a comprehensive overview on the use of infographics in education, its implementations and reflections in teaching mathematics and how to use infographics for individuals with mathematical learning difficulties to facilitate their learning in mathematics.

\section{MATERIALS AND METHODS}

Research model, data collection and data analysis of the present study are provided in this section.

\subsection{Research model}

This study is based on a comprehensive literature review which aims to generate a perspective on the facilitative role of infographics for individuals with special needs. In line with the aim of the, document analysis as a qualitative research method was used. Document analysis includes the detailed examination of written materials which includes information about phenomenon or phenomena targeted to be analyzed and identification of certain categories from the analysis of the documents
(Yildirim and Simsek, 2013). Documents are crucial resources in qualitative research design. Bowen (2009) emphasized that document analysis method is the analysis of published, written materials about a phenomenon. Accordingly, a detailed analysis of information in published documents is considered for a systematic examination and review in the present study.

\subsection{Data collection and analysis of the data}

Published materials in academic journals and books about infographics were examined in this study through a comprehensive literature review. Accordingly, relevant materials especially articles and books were identified by the researchers. All selected materials were read and interpreted by each researcher separately. Then, all materials and interpretations were brought together to obtain common categories and researchers evaluated these categories together. Lastly, these categories were analyzed in detail in order to constitute a framework for important dimensions based on the aim of the study.

After collecting the relevant documents from various different resources involving especially books and academic journals, theoretical and practical inferences were made from texts from the documents in line with the aim of the present study. In data analysis process, data were interpreted in a comprehensive way by categorizing the data as defining infographics, efficient use of infographics in general education and settings and reflections and discussion of implications of using infographics for facilitating learning of individuals with special needs. Lastly, documents were brought together in order to constitute a meaningful whole and results of the study were obtained in this way.

\section{RESULTS}

\subsection{Effectiveness of using infographics in education}

The word "infographic" includes two words; "info" and "graphic" and it is the short form of "information graphic." Infographics is visualization method for presenting complicated information in an effective way and it is mainly about visually presenting and 
representing data. Recently, infographics has gained great importance based on the continuous increasing in the amount of information and rapid advancement in the social media (Borucu, 2015). In addition, Rajamanickam (2005) mentioned about certain principles for designing infographics. These principles involve organizing information, making information visible, forming a content, making it simple, adding multiple emphasis, showing cause and effect relationship and constituting integrated graphics.

In additon to the effective use of infographics in graphic design and visual communication (Brumberger, Lauer and Northcut, 2013), the use of infographics as a tool in education has become a recent trend. Accordingly; Shafipoor, Sarayloo and Shafipoor (2016) stated that the use of educational technologies in teaching has many benefits for both students and teachers and use of infographics help learners to realize remarkable amount of information at once and keep the information in their minds for a long period of time. In addition, Ciftci (2016) examined the effect of using infographics on student achievement and attitudes towards geography lessons and showed that infographics is an effective way in improving student achievement in geography lessons and triggering positive attitudes towards the lecture. Nevertheless, the effective use of infographics has been found to be beneficial in other areas or levels of education including higher education (Taguchi and Ackerman, 2014), foreign language teaching (Pisarenko and Bondarev, 2016), science education (Davidson, 2014), visual communication design education (Dur, 2014), teaching mathematics (Sudakov, Bellsky, Usenyuk and Polyakova, 2015), creating awareness on environmental issues (Tuncali, 2016) and anatomy education (Ozdamli, Kocakoyun, Sahin and Akdag, 2016). Matrix (2014) also indicated that infographics is an important component for constituting pedagogical approach in drawing on visual materials, it increases social engagement, critical thinking and writing. An infographic for summarizing the functions of infographics are given in Figure 2.

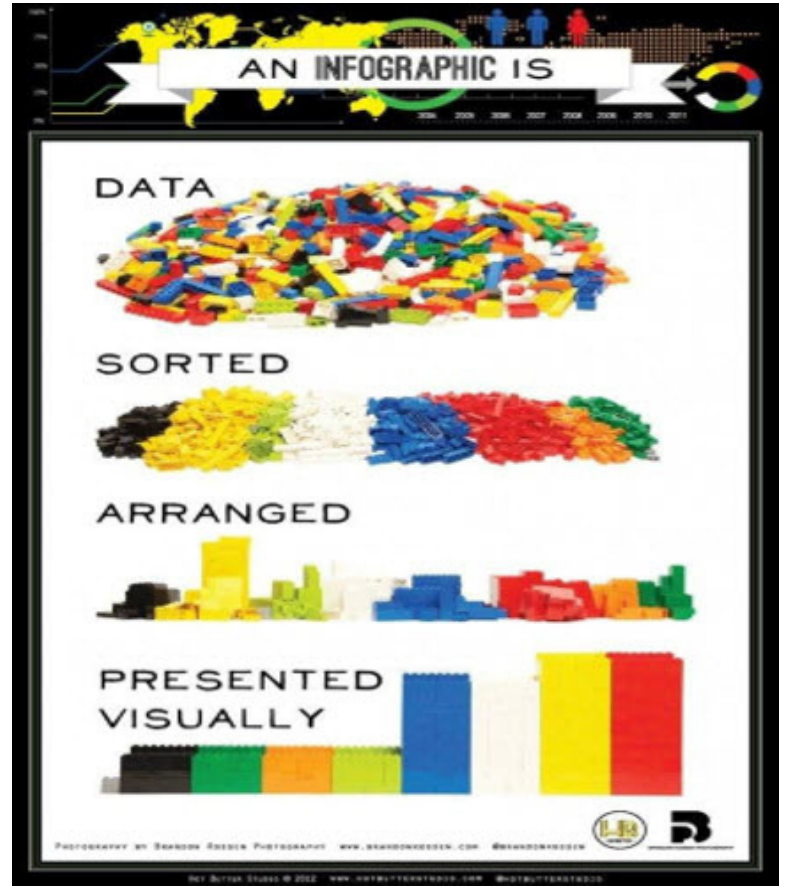

Figure 2. What is an infographic? Retrieved from: https://visual.ly/community/infographic/how/what-infographic

Furthermore, Kibar and Akkoyunlu (2017) revealed that students can be motivated to generate their own content through visualizing the content and in order to achieve this, they can use infographics. On the other hand, individuals with special needs require help and support in learning many concepts and skills in terms of both academic and social aspects. When the literature is examined, it is seen that the use of new technologies in special education has increased and it has been shown that it is efficient to integrate technology in special education (Liu, Wu and Chen, 2013). Therefore, it can be inferred that use of infographics for individuals with special needs might be a beneficial way for enhancing their learning and infographics might be a good method for this enhancement.

\subsection{Mathematical learning difficul- ties: dyscalculia}

Before 1965 's, learning difficulties did not exist in special education books, however; it frequently exists now (Dogru, 2012). Learning difficulties are primarily related with various deficits in comprehension, organization, learning outcome, achievement and using verbal and non-verbal knowledge. Learning difficulties show variability in terms of the severity of symptoms from mild, moderate and 
severe. Furthermore, learning difficulties can be described based on the difficulties in using or acquiring several skills including:

- Verbal language (listening, speaking and understanding)

- Reading (reading comprehension and interpretation)

- Written language (relying on the orthographic rules, written expressions) and solving)

- Mathematics (calculation, problem

In addition to these skills, individuals with learning difficulties might experience difficulties in establishing or maintaining social relationships. Commonly observed characteristics of learning difficulties are attention deficit and hyperactivity, normal or higher level of intelligence level, coordination difficulties, impulsivity, difficulties in academic skills, sensory difficulties in terms of visual, auditory, kinesthetic, tactile and spatial perceptions. Selcuk (2002) categorized and summarized the possible problems of children with learning difficulties and these are demonstrated in Table 1.

Table 1. Possible problems of children with learning difficulties, Selcuk (2002)

\begin{tabular}{cl}
\hline $\begin{array}{c}\text { Problem } \\
\text { areas }\end{array}$ & \multicolumn{1}{c}{ Problems } \\
\hline General & $\begin{array}{l}\text { Attention deficit, hyperactivity, } \\
\text { lack of coordination and } \\
\text { balance, not being able to } \\
\text { complete homework, being } \\
\text { competent in one area and } \\
\text { having difficulties in other areas }\end{array}$ \\
\hline & $\begin{array}{l}\text { Not being able to remember } \\
\text { mathematical concepts, }\end{array}$ \\
Mathematics & $\begin{array}{l}\text { difficulties in problem solving, } \\
\text { mixing values in addition } \\
\text { operation }\end{array}$ \\
Reading & $\begin{array}{l}\text { Not being able to concentrate in } \\
\text { reading, not being able read } \\
\text { fluently and follow the line in } \\
\text { the text }\end{array}$ \\
\hline Writing & $\begin{array}{l}\text { Writing very slowly, writing the } \\
\text { letters in a wrong way }\end{array}$ \\
\hline
\end{tabular}

As it can be seen from Table 1, individuals with learning difficulties might experience difficulties in certain domains including general, mathematics, reading and writing. Furthermore, since individuals with learning difficulties experience difficulties primarily in academic skills such as reading, writing and mathematical skills, they are more likely to be identified and diagnosed when they start to school. Considering these difficulties, diagnosis of mathematical learning difficulty has dramatically increased today. Mathematical learning difficulty is also referred to as dyscalculia which also specifies the terms as a disorder affecting mathematical competence of the individual while learning or implementing basic mathematical concepts and operations (Akin and Sezer, 2010).

Children and adolescents with mathematical learning difficulty might experience difficulties in learning numbers, counting numbers, making mathematical operations with fingers, difficulties in reading clock, solving mathematical problems, knowing right and left sides, continuing writing on a straight line and difficulties in mathematical algorithms (American Psychiatric Association, 2013; Asfuroglu and Fidan, 2016) and the prevalence of mathematical learning difficulties is between $5 \%$ and $8 \%$ among schoolaged children (Hakkarainen, Holopainen and Savolainen, 2013). There are various teaching approaches for children with mathematical learning difficulties as in special education and one of the most important way of enhancing their teaching is to teach them various learning strategies. In addition, it is generally known that use of visuals in teaching mathematics enhances learning since it makes abstract mathematical concepts or skills more concrete (Isik and Konyalioglu, 2005).

\subsection{Use of visuals to enhance learn- ing mathematics in individuals with mathematical learning difficulties}

Individuals can easily learn concrete things and it would be better to benefit from concrete visual materials in teaching (Yolcu and Kurtulus, 2010). Accordingly, it would be appropriate to include activities for students to improve their visualization skills and lead them to thinking visually (Yilmaz and Argun, 2013) in order to increase their achievement and develop positive attitudes towards mathematics (Kog and Baser, 2012) and this might be achieved through using visual technologies in teaching (Uzunboylu and Tugun, 2016). In addition, visualization in mathematics is the process of shaping mages in individuals' minds through paper and pencils or technological tools and using visuals to explore and understand mathematics. From the beginning of the process of learning a subject in mathematics to the end of the process, understanding of the subject and ensuring permanence and Kog and Baser (2011) showed that visualization in mathematics have a positive impact on learned helplessness and abstract thinking in mathematics.

Primary aim of teaching mathematics is to transform mathematical knowledge to students and develop mathematical thinking 
skills among students (Bozkurt and Akalin, 2010). It is stated that visualization process might involve envisioning an object or an event or transforming a structure through an interactive visual tool to the physical world. In fact, it is obvious that use of visualization in mathematics education can positively affect students in terms of cognitive and sensory aspects. For this reason, it is also important to use visualization in teaching mathematics to individuals with mathematical learning difficulties since it makes mathematical concepts more concrete and it can appeal to more than one sense at once. It is also known that visualization attracts attention, increases motivation and helps students to organize information (Presmeg, 2014). These are the main points in which individuals with mathematical learning difficulties need support and therefore it can be inferred that use of visualization should be frequently used to enhance learning of individuals with mathematical learning difficulties.

\subsection{Use of infographics for indi- viduals with mathematical learning difficulties}

Through the use of infographics; instructional purposes, understanding the subjects, reinforcement and learning are achieved through based on visual methods. Figure 3 shows an example for infographics which can facilitate certain subjects of mathematics with infographics. As it can be seen from Figure 3 , addition and subtraction, shapes, numbers and place value subjects can be visualized and presented with infographics. In this way, individuals with mathematics learning difficulties are able to keep information in their minds, understand the subject and organize complex information.

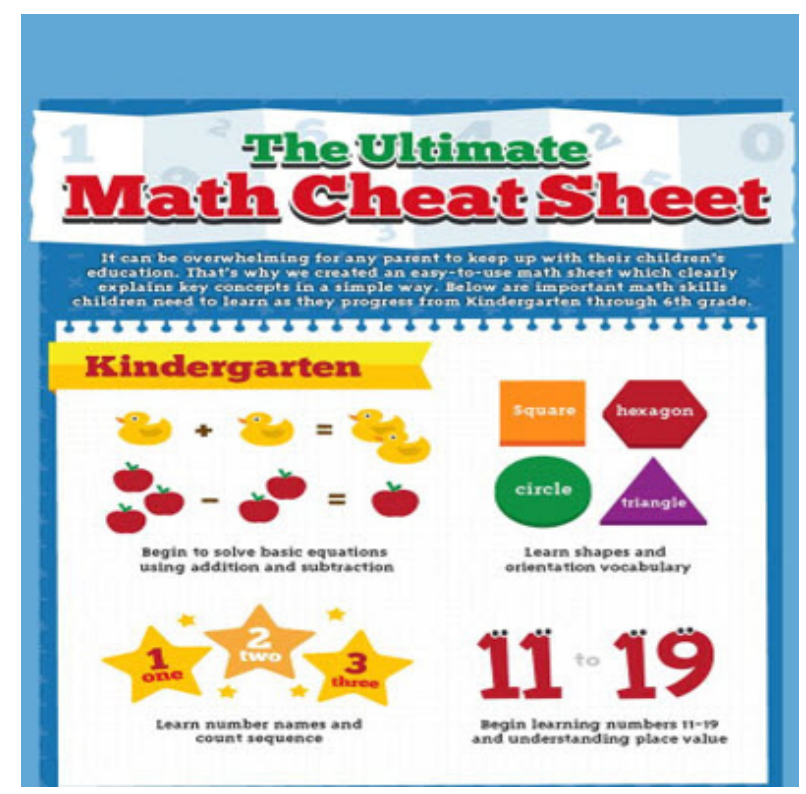

Figure 3. An infographics for teaching mathematics. Retrieved from: http://elearninginfographics.com/the-ultimate-mathcheat-sheet-infographic/

\section{DISCUSSION}

Mathematics has a facilitative role in both individuals with special needs and individuals with typical development. In this regard, it is necessary for individuals with special needs to acquire mathematical skills. Mathematics is important for individuals to reason, think critically, solve problems, it contributes to improve mental skills of individuals and use these skills in their daily lives (Virtop, 2016). Some children have difficulties in mathematics and these difficulties might occur based on the structure of mathematics, teaching method and individual differences among students (Karabulut, Yikmis, Ozak and Karabulut, 2015) and it is known that these individual differences are often manifested as mathematical learning difficulties, namely dyscalculia.

Visualization basically involves making abstract thinking more concrete or picturizing information and therefore it can be said that it can make invisible things more visible. Visual components provide opportunity for this and they make concepts get rid of being abstract and they give meaning to processes. Visual components have very important functions including providing and supporting information, attracting attention, summarizing the content of the subject, showing the relationships between concepts and phenomenon and making complex subjects more clear (Dursun and Esgi, 2008). Visualization in mathematics education 
can be supported with infographics. Since the use of diagrams and graphics in mathematics is known to be beneficial, infographics can also be used to faciliatate learning. Teachers can explain mathematical subjects with infographics. Aim of infographic design is to explain a concept or an idea in the most appropriate way for the individual. In general, readability and clarity are the most important criteria for infographics. Nowadays, teachers are expected to have necessary knowledge and skills for integrating technological innovations (Stemberger and Cencic, 2016) and infographics in education (Islamoglu, Ay, Ilic, Mercimek, Donmez, Kuzu and Odabasi, 2015).

It is known that use of interactive graphical visuals is beneficial in special education and Takacs (2005) also mentioned that interactive computer graphics are used to increase learning efficiency. When infographics is used in mathematics, mathematical concepts are presented in a clear way and students can understand easily. For students, mathematics becomes attractive and enjoyable. From a theoretical perspective, information processing model speculates that learning is achieved when the learner pays attention to the external stimuli, records and sends it to short-term memory, then organizes it with existing information and send it to long-term memory. According to Gulten, Ergin and Avci (2009) use of information processing model as the basis in teaching enhances learning in mathematics. When it is considered that paying attention and organizing information are crucial components of infographics and their importance in mathematics, it can be inferred that information processing model as a theoretical perspective helps to understand the importance of using attractive and clear stimuli in teaching mathematics.

In a recent study by Singh and Jain (2017), it is mentioned that using infographics in teaching mathematics to students with dyscalculia increases students' interest, motivation and achievement when compared to using traditional methods in teaching mathematics and the researchers recommended that effective infographics should be used to make students with dyscalculia curious to learn mathematics since they can focus on the figures, diagrams and images in infographics and therefore they begin to analyze the images and learn.

\section{CONCLUSSION AND RECOMMENDATIONS}

Rapid advances and innovations in technology bring new opportunities to use in education and infographics is one of these opportunities since it includes data visualization which is beneficial in enhancing learning of individuals. In the field of mathematics education, the importance of technology is understood for many years and infographics design has begun to be used recently. In conclusion, the present study provided a comprehensive overview on what is infographics, the effectiveness of using infographics in education and discussed the possible facilitative role of infographics in enhancing the learning of individuals with mathematical learning difficulties.

In the light of the results obtained from the study, the following recommendations for further research and practices are provided:

- It would be better to increase the use of infographics as a strategy for individuals with mathematical learning difficulties to enhance their learning.

- Special education teacher training programs should include more lectures on using visual technologies involving infographics.

- Seminars, conferences and in-service trainings might be organized for special education teachers to increase their skills on integrating infographics into education.

- Further research might conduct experimental or quantitative studies in order to reveal the effectiveness of teaching practices supported with infographics for individuals with mathematical learning difficulties.

- Families should become more aware on using visuals for their children with mathematical learning difficulties to support their education.

\section{Conflict of interests}

The authors declare no conflict of interest.

\section{REFERENCES}

Akin, A., \& Sezer, S. Diskalkuli: Matematik ogrenme bozuklugu. Bilim ve Aklin Aydinliginda Egitim, (126-127), 41-48. URL: http://vizyon21y.com/ documan/Egitim Ogretim/Rehberlik/Rehberlik_Makale/Diskālkuli_Matematik_Ogrenme_ Bozuklugu.pdf

American Psychiatric Association, (2013). Diagnostic and Statistical Manual of Mental Disorders (5th ed.) Washington, DC: Author. URL: https://dsm. 
(IJCRSEE) International Journal of Cognitive Research in Science, Engineering and Education Vol. 5, No. 2, 2017.

psychiatryonline.org/doi/book/10.1176/appi. books.9780890425596

Asfuroglu, B. O., \& Fidan, S. T. (2016). Ozgul ogrenme guclugu. Osmangazi Journal of Medicine, 38(1), 49-54. URL: http://dergipark.ulakbim.gov.tr/ otd/article/view/5000178173

Borucu, A. (2015). Contribution of infographics for teaching technique in fine arts high school during the graphic lesson. (Unpublished master thesis). Suleyman Demirel Universitesi / Guzel Sanatlar Enstitusu, Isparta. URL: http://library. sdu.edu.tr/veritabanlari/Tezler

Bowen, G. A. (2009). Document analysis as a qualitative research method. Qualitative Research Journal, 9(2), 27-40. doi: https://doi.org/10.3316/ QRJ0902027

Bozkurt, A., \& Akalin, S. (2010). Matematik ogretiminde materyal gelistirmenin ve kullaniminin yeri, onemi ve bu konuda ogretmenin rolu. Dumlupinar Universitesi Sosyal Bilimler Dergisi, (27), 47-56. URL: http://dergipark.gov.tr/ dpusbe/issue/4769/65596

Brumberger, E., Lauer, C., \& Northcut, K. (2013). Technological literacy in the visual communication classroom. Programmatic Perspectives, 5(2), 171-196. URL: http://www.cptsc.org/pp/ vol5-2/brumbergeretal.pdf

Bulduk, B. (2016). Contemporary illustration methods and new application areas on illustrations: interaction induced animated illustrations. Global Journal of Arts Education, 6(3), 77-84. doi: https://doi.org/10.18844/gjae.v6i3.1699

Chen, P., \& McGrath, D. (2005). Visualize, visualize, visualize: Designing projects for higher-order thinking. Learning \& Leading with Technology, 32(4), 54-57. URL: https://eric. ed.gov/?id=EJ697296

Cifci, T. (2016). Effects of infographics on students achievement and attitude towards geography lessons. Journal of Education and Learning, 5(1), 154-166. doi: http://dx.doi.org/10.5539/jel. v5n 1 p 154

Davidson, R. (2014). Using infographics in the science classroom. The Science Teacher, 81(3), 34-39. URL: https://search.proquest.com/openview/ 93d7bd2c0ae5b76c6a0ba3e7cad7ebd4/1?pqorigsite $=$ gscholar\&cbl $=40590$

Davis, M., \& Quinn, D. (2013). Visualizing text: The new literacy of infographics. Reading Today, 31(3), 16-18. URL: http://kimberleyhaile7490p1.wikispaces.com/file/view/7490 Haile_P2\%20Article2.pdf/489892154/7490 Haile P2\%20Article2.pdf

Dick, M. (2013). Interactive infographics and news values. Digital Journalism, 2(4), 1-17. doi: https:// doi.org/10.1080/21670811.2013.841368

Dogru, S. Y. (2012). Ogrenme guclukleri. Ankara: Egiten Kitap. (Printed Book)

Dur, B. I. U. (2014). Data visualization and infographics in visual communication design education at the age of information. Journal of Arts and Humanities, 3(5), 39-50. doi: http://dx.doi. org/10.18533/journal.v3i5.460

Dursun, F. \& Esgi, N. (2008). 4. ve 5. sinif sosyal bilgiler ogretimi ders kitaplarinin gorsel tasarim ilkelerine gore degerlendirilmesi. Gazi Universitesi Endustriyel Sanatlar Egitim Fakultesi Dergisi, 22, 21-34. URL: http://dergipark.gov.tr/esef/issue $/ 28799 / 308151$

Gulten, D. C., Ergin, H., \& Avci, R. (2009). Bilgiyi is- leme kurami ve anlamlandirmanin matematik ogretimi uzerindeki etkisi. Hasan Ali Yucel Egitim Fakultesi Dergisi, 6(2), 1-10. URL: http:// dergipark.gov.tr/download/issue-file/3119

Hakkarainen, A., Holopainen, L., \& Savolainen, H. (2013). Mathematical and reading difficulties as predictors of school achievement and transition to secondary education. Scandinavian Journal of Educational Research, 57(5), 488-506. URL: https://doi.org/10.1080/00313831.2012.696207

Isik, A., \& Konyalioglu, A. C. (2005). Matematik egitiminde gorsellestrme yaklasimi. Atatürk Universitesi Kazim Karabekir Egitim Fakultesi Dergisi, (11), 462-471. URL: http://e-dergi.atauni. edu.tr/ataunikkefd/issue/view/1021000289

Islamoglu, H., Ay, O., Ilic, U., Mercimek, B., Donmez, P., Kuzu, A., \& Odabasi, F. (2015). Infographics: A new competency area for teacher candidates. Cypriot Journal of Educational Sciences, 10(1), 32-39. URL: http://sproc.org/archives/index. $\mathrm{php} / \mathrm{cjes} /$ article/view/10_5/pdf_3504

Karabulut, A., Yikmis, A., Ozak, H., \& Karabulut, H. (2015). Semaya dayali problem cozme stratejisinin zihinsel yetersizligi olan ogrencilerin problem cozme performanslarina etkisi. Abant Izzet Baysal Universitesi Egitim Fakultesi Dergisi, 15, 243-258. URL: http://efdergi.ibu.edu.tr/index.php/efdergi/article/viewFile/1481/2346

Keller, T., \& Tergan, S. O. (2005). Visualizing knowledge and information: An introduction. In Knowledge and information visualization. Berlin: Springer, Heidelberg. URL: https://link. springer.com/chapter/10.1007\%2F11510154 1

Kibar, K. P., \& Akkoyunlu, B. (2017). Fostering and assessing infographic design for learning: the development of infographic design criteria. Journal of Visual Literacy, (1), 1-18. doi: https://doi. org/10.1080/1051144X.2017.1331680

Kog, O. U., \& Baser, N. E. (2011). The effect of visualization approach on learned helplessness and abstract thinking in mathematics. Bati Anadolu Egitim Bilimleri Dergisi, 1(3), 89-108. URL: http://dergipark.ulakbim.gov.tr/baebd/article/ view/5000057251

Kog, O. U., \& Baser, N. (2012). The role of visualization approach on students' attitudes towards and achievements in mathematics. Ilkogretim Online, 11(4), 945-957. URL: http:// dergipark.ulakbim.gov.tr/ilkonline/article/ view/5000037832/5000036690

Liu, G. Z., Wu, N. W., \& Chen, Y. W. (2013). Identifying emerging trends for implementing learning technology in special education: A state-ofthe-art review of selected articles published in 2008-2012. Research in Developmental Disabilities, 34(10), 3618-3628. URL: https://www. ncbi.nlm.nih.gov/pubmed/23962607

Matrix, S., \& Hodson, J. (2014). Teaching with infographics: Practicing new digital competencies and visual literacies. Journal of Pedagogic Development, 4(2), 17-27. URL: http:// uobrep.openrepository.com/uobrep/handle/10547/335892

Meeusah, N., \& Tangkijviwat, U. (2013). Effect of data set and hue on a content understanding of infographic. ACA2013 Thanyaburi: Blooming Color for Life December, 11-14. URL: http://www.repository.rmutt.ac.th/bitstream/ handle/123456789/1263/EFFECT\%20OF\%20 DATA $\% 20$ SET $\% 20$ AND $\% 20 H U E \% 20$ ON.... 
pdf? sequence $=1$

Ozdamli, F., Kocakoyun, S., Sahin, T., \& Akdag, S. (2016). Statistical reasoning of impact of infographics on education. Procedia Computer Science, 102, 370-377. doi: https://doi. org/10.1016/j.procs.2016.09.414

Presmeg, N. (2014). Contemplating visualization as an epistemological learning tool in mathematics. ZDM-The International Journal on Mathematics Education, 46(1), 151-157. doi: https:// doi.org/10.1007/s11858-013-0561-Z

Pisarenko, V., \& Bondarev, M. (2016). Infographics use in teaching foreign languages for specific purposes. Recent Patents on Computer Science, 9(2), 124-132. URL: http://en.ustc. findplus.cn/?h=articles $\& \mathrm{db}=$ edselc $\& a n=$ edse lc. $2-52.0-84981716524$

Rajamanickam, V. (2005). Infographics seminar handout. Ahmedabad, Disponível em: Andlt. URL: http://www.schrockguide.net/uploads/3/9/2/2/392267/infographic_handout.pdf

Saban, A. (2002). Coklu zeka teorisi ve egitim. Ankara: Nobel Yayin Dagitim. (Printed Book)

Schroeder, R. (2004). Interactive Info Graphics in Europe--added value to online mass media: A preliminary survey. Journalism Studies, 5(4), $563-$ 570. doi: https://doi.org/10.1080/14616700412 331296473

Selcuk, Z. (2002). Dikkat eksikligi ve hiperaktif cocuklar. Ankara: Pegem Yayincilik. (Printed Book)

Shafipoor, M., Sarayloo, R., \& Shafipoor, A. Infographic (information graphic); a tool for increasing the efficiency of teaching and learning processes. International Academic Journal of Innovative Research, 3(4), 39-45. URL: http://iaiest. com/dl/journals/8-\%20IAJ\%20of\%20Innovative\%20Research/v3-i4-Apr2016/paper5.pdf

Singh, N., \& Jain, N. (April 2017). Effects of infographic designing on image processing ability and achievement motivation of dyscalculic students. Proceedings of the International Conference for Young Researchers in Informatics, Mathematics and Engineering. Kaunas, Lithuania. URL: http://ceur-ws.org/Vol-1852/p08.pdf

Smiciklas, S. (2011). 100 things every designer needs to know about people. Indiana, U.S.A: Que Publishing. URL: http://www.landlessons.org/ book/432519291/download-100-things-everydesigner-needs-to-know-about-people-susanweinschenk.pdf

Stemberger, T., \& Cencic, M. (2016). Design based research: The way of developing and implementing. World Journal on Educational Technology: Current Issues, 8(3), 180-189. doi: https://doi. org/10.18844/wjet.v8i3.621

Sudakov, I., Bellsky, T., Usenyuk, S., \& Polyakova, V. V. (2016). Infographics and mathematics: A mechanism for effective learning in the classroom. PRIMUS, 26(2), 158-167. doi: https://doi. org/10.1080/10511970.2015.1072607

Taguchi, K., \& Ackerman, L. (2014, October). The infographic: Is there a place in higher education? In E-Learn: World Conference on E-Learning in Corporate, Government, Healthcare, and Higher Education, 1901-1905. Association for the Advancement of Computing in Education (AACE). URL: https://www.learntechlib. org/p/148882/

Takacs, B. (2005). Special education and rehabilitation: Teaching and healing with interactive graphics.
IEEE Computer Graphics and Applications, 25(5), 40-48. URL: http://ieeexplore.ieee.org/ abstract/document/1510538/

The Ultimate Math Cheat Sheet Infographic. (2014, 31 March). Retrieved on: 28 June 2017, http:// elearninginfographics.com/the-ultimate-mathcheat-sheet-infographic/

Tong, Y., \& Bakan, M. (2016). A mobile visualization platform for exploring social media data. Global Journal of Information Technology, 6(1), 27-33. doi: http://dx.doi.org/10.18844/gjit.v6i1.386

Tuncali, E. (2016). The infographics which are designed for environmental issues. Global Journal on Humanites \& Social Sciences, 2(1), 14-19. doi: https://doi.org/10.18844/gjhss.v2i1.272

Uzunboylu, H., \& Tugun, V. (2016). Validity and reliability of tablet supported education attitude and usability scale. Journal of Universal Computer Science, 22(1), 82-93. URL: https://pdfs.semanticscholar.org/15c8/0933ac54775bd93cef472ab 9847e8c7ebe96.pdf

Virtop, S. A. (2016). Challenging paradigms in the continuous training of teachrs with regard to the curricular areas of mathematics and Science. Contemporary Educational Researches Journal, 6(2), 41-48. doi: https://doi.org/10.18844/cerj. v6i2.860

Ware, C., \& Bobrow, R. (2005). Supporting visual queries on medium-sized node-link diagrams. Information Visualization, 4(1), 49-58. URL: http://journals.sagepub.com/doi/abs/10.1057/ palgrave.ivs.9500090

Weinschenk, M. (2012). The power of infographics. U.S.A.: New Riders. URL: http://ptgmedia. pearsoncmg.com/images/9780789749499/samplepages/0789749491.pdf

What is an infographic?. (2012, 10 July). Retrieved on: 25 May 2017, https:/visual.ly/community/infographic/how/what-infographic

Williams, F. M. (2002, July). Diversity, thinking styles, and infographics. In Proc., $12^{\text {th }}$ International Conference of Women Engineers and Scientists, Atlantic Region Faculty of Engineering and Applied Science, Memorial University St. John's, NF Canada. Retrieve from: http://www.mun.ca/ cwse/icwes infographics.pdf

Yildirim, A. \& Simsek, H. (2013). Sosyal bilimlerde nitel arastirma yontemleri (Extended $9^{\text {th }}$ edition). Ankara: Seckin Publications. (Printed Book)

Yilmaz, R., \& Argun, Z. (2013). Matematiksel genelleme surecinde gorsellestirme ve onemi. Hacettepe Universitesi Egitim Fakultesi Dergisi, 28(2), 564-576. URL: http://www.efdergi. hacettepe.edu.tr/yonetim/icerik/makaleler/202published.pdf

Yolcu, B., \& Kurtulus, A. (2010). 6. sinif ogrencilerinin uzamsal gorsellestirme yeteneklerini gelistirme uzerine bir calisma. Ilkogretim Online, 9(1), 256-274. URL: http://dergipark.gov.tr/download/article-file/90807 